\title{
Kloning Gen Penyandi Antigen HBsAg100 dalam Rangka Produksi Protein Rekombinan Sebagai Model Imunogen untuk Menghasilkan Antibodi
}

\section{Gene Cloning Encoder HBsAg100 Antigen in Recombinant Protein Production Order for Models to Generate Antibody Immunogen}

\author{
S. Riyadi $^{1}$, R. RA Maheswari ${ }^{2}$, M. Sudarwanto ${ }^{3}$, \\ Fransiska RZ ${ }^{4}$, dan M. Ali ${ }^{1}$ \\ ${ }^{1}$ Laboratorium Mikrobiologi dan Bioteknologi Fakultas Peternakan UNRAM \\ ${ }^{2}$ Fakultas Peternakan IPB \\ ${ }^{3}$ Fakultas Kedokteran Hewan IPB \\ ${ }^{4}$ Fakultas Teknologi Pertanian IPB \\ e-mail: riyadi_unram@yahoo.com
}

(Diterima: 14 Februari 2011; Disetujui: 21 September 2011)

\begin{abstract}
Since one decade ago, a new paradigm of vaccine design is emerging. Instead of attenuated virulent microorganisms or killed virulent microorganisms, effective subunit vaccines were developed using recombinant DNA technology. By using the technology, selected genes of the virulent microorganisms can be cloned, expressed, and evaluated as vaccine components. In this research, hydrophilic domain of $S$ protein (aa 100-164)-encoding gene of hepatitis $B$ surface antigen was cloned for vaccine candidate production. The gene was ligated with $p G E X-4 T-2$ vector and sequenced. Sequences aligment of the amplified fragment with genome of hepatitis $B$ virus indicated that the sequences were identical. A major result achieved from this research was clones carrying $S$ antigens-encoding gene that could be used further for production of recombinant hepatitis $B$ vaccine candidates.
\end{abstract}

Keywords: antibodi, PCR, $p G E X$, hepatitis B, vaksin

\section{PENDAHULUAN}

Teknologi kloning merupakan terobosan baru di bidang rekayasa genetika. Menurut Winarno dan Agustinah (2007), kloning adalah pengembangbiakan suatu mahluk hidup yang persis sama dengan induknya tanpa melalui pembuahan, seperti stek pada tanaman, tetapi kloning melalui rekayasa genetika jauh lebih rumit. Muladno (2002) menjelaskan, bahwa pada prinsipnya kloning DNA adalah proses penggandaan jumlah DNA rekombinan melalui proses perkembangbiakan sel bakteri (biasanya $E$. coli). Proses penggandaan tersebut dilakukan dengan memasukkan DNA rekombinan ke dalam E.coli, diikuti dengan inkubasi sel E.coli pada suhu optimal sehingga sel berkembangbiak secara eksponensial. Selanjutnya dijelaskan pula, bahwa menggandakan jumlah molekul DNA tidak hanya dapat dilakukan dengan memanfaatkan mekanisme kehidupan mikroorganisma, tetapi dapat juga dilakukan melalui teknik PCR (Polymerase Chain Reaction).

Perkembangan teknologi molekuler (seperti kloning) yang sangat pesat telah membuka era baru dalam menghasilkan berbagai jenis vaksin maupun obat yang dibutuhkan oleh hewan maupun manusia. Penggunaan teknologi tersebut telah memudahkan dihasilkannya berbagai sub unit vaksin yang jauh lebih efektif jika dibandingkan dengan vaksin yang dihasilkan dengan teknologi konvensional menggunakan mikroorganisme virulen yang dilemahkan ataupun telah dibunuh.

Indonesia merupakan daerah endemis sedang sampai tinggi untuk penyakit 
hepatitis B,oleh karena itu, pada tahun 1987, WHO menetapkan Pulau Lombok sebagai model imunisasi masal hepatitis B pertama di dunia. Hasil proyek tersebut menunjukkan penggunaan vaksin konvensional mampu menurunkan prevalensi hepatitis B hanya sampai 70\% (Mulyanto et al., 2002). Hasil imunisasi tersebutdinyatakan belum optimal, hal ini antara lain disebabkan karena vaksin konvensional yang digunakan (Korean Green Cross) berasal dari plasma darah orang asing sehingga tidak mampu menstimulasi munculnya tanggap kebal (antibodi) spesifik yang mampu melawan virus hepatitis B yang terdapat di Indonesia (Joung et al., 2004).

Berdasarkan permasalahan tersebut, pada penelitian ini dilakukan rekayasa terhadap gen penyandi antigen permukaan hepatitis B untuk menghasilkan antigen HBsAgpada E. coli dengan menggunakan teknologi rekombinan. Kendala utama produksi antigen tersebut pada bakteri $E$. coli adalah tingkat ekspresinya sangat rendah (Maruyama et al., 2000). Rendahnya tingkat ekspresi tersebut disebabkan oleh bagian hidrofobik (Lu et al., 2002; Kumar et al., 2005). Oleh karena itu, pada penelitian ini bagian yang dikloning adalah bagian penyandi epitop yang bersifat hidrofilik (dari asam amino 100-164). Selain itu, gen penyandi antigen permukaan hepatitis B di atas akan digabung (fusi) dengan gen penyandi enzim gluthation-S-transferase (GST) untuk meningkatkan ekspresi maupun solubilitas antigen yang sangat penting untuk aktivitas maupun proses purifikasi (Sheu et al., 1995; Vikis and Guan, 2000; Koschoreck et al., 2005). Gen penyandi antigen permukaan hepatitis B yang digunakan pada penelitian ini adalah gen yang diisolasi dari virus hepatitis B sub tipe $a d w$ sebagai subtype utama di Indonesia. Hal ini dimaksudkan untuk membuat kandidat vaksin galur lokal yang mampu memberikan respon antibodi yang spesifik sesuai dengan genetik virus hepatitis B yang terdapat di Indonesia.

Dihasilkannya kandidat vaksin hepatitis B rekombinan dengan teknologi rekayasa DNA menggunakan bakteri ini akan menggantikan metode produksi vaksin konvensional dari plasma yang memiliki kelemahan seperti rendahnya imunogenisitas, sumber plasma yang terus berkurang (karena jumlah penderita penyakit hepatitis B menurun sejalan dengan keberhasilan vaksinasi), serta kekhawatiran adanya kontaminasi penyakit lain pada serum donor. Karena gen penyandi antigen tersebut diisolasi dari virus hepatitis B yang terdapat di Indonesia, maka antigen ini diharapkan dapat menghasilkan kandidat vaksin rekombinan hepatitis B yang sesuai dengan genetik virus tersebut di Indonesia.

\section{METODE}

Untuk mengamplifikasi fragmen $\mathrm{S}$ (asam amino nomor 100-164) dari gen penyandi antigen permukaan virus hepatitis $\mathrm{B}$, digunakan plasmid pGET-HB (disediakan oleh Prof. Mulyanto, Laboratorum Hepatitis Mataram) yang membawa gen-gen permukaan virus hepatitis B sebagai cetakan. Untuk amplifikasi tersebut, digunakan primer HBVS.100(f) (5'-TATCAAGGTATGTTGCCCGTTTG -3') dan HBVADWS (r) (5'-AAGCTTCATTACTCCCATAGGTATTTTGCGAAAG-3'). Enzim DNA polimerase yang digunakan adalah enzim pyrobest (Takara Bioinc., Otsu, Japan). Fragmen tersebut kemudian diligasi dengan teknik Kloning TA menggunakan vektor pGEX-4T-2 (Pharmacia). Plasmid rekombinan tersebut kemudian ditransformasi ke bakteri E. coli DH5a. Kultur bakteri dilakukan pada media Luria Bertani. Sedangkan isolasi plasmid untuk sekuensing digunakan Kit Nucleospin (Macherey, Nalgen).

\section{Amplifikasi gen penyandi HBsAg100}

Campuran PCR yang digunakan adalah 0,1 unit enzim DNA polymerase pyrobest (Takara Bioinc., Otsu, Japan) dengan bufernya; $0,5 \mu \mathrm{M}$ primer forward (f) dan reverse (r); 0,2 $\mathrm{mM}$ dNTP; $1 \mathrm{ng} / \mathrm{ml}$ 
plasmid pGEMT-HB sebagai cetakan. Program PCR yang digunakan adalah denaturasi awal pada suhu $94^{\circ} \mathrm{C}$ selama 5 menit ; siklus yang terdiri dari denaturasi pada $94^{\circ} \mathrm{C}$ selama 30 detik, annealing pada suhu $54^{\circ} \mathrm{C}$ selama 30 detik dan elongasi (ekstensi) pada suhu $72^{\circ} \mathrm{C}$ selama 30 detik; diakhiri dengan $72^{\circ} \mathrm{C}$ selama 5 menit dan $20^{\circ} \mathrm{C}$ sampai sampel diangkat untuk dielektroforesis.

\section{Konstruksi plasmid rekombinan}

Hasil PCR kemudian dimurnikan dengan DNA Gel extraction kit dan diligasi dengan plasmid pGEX-4T-2 (Pharmacia) yang telah dipotong dengan enzim Sma1. Campuran reaksi dari ligasi tersebut adalah produk PCR $2 \mu \mathrm{l}, 25 \mathrm{ng} / \mu \mathrm{l}$ pGEX-4T-2, $1 \mu \mathrm{l}$ kit ligasi, dilanjutkan dengan inkubasi pada suhu $12^{\circ} \mathrm{C}$ selama 18 jam. Setelah itu, transformasi dilakukan dengan E. coli $\mathrm{DH} 5 \alpha$ untuk kemudian ditumbuhkan pada media LB yang mengandung ampicilin pada suhu $37^{\circ} \mathrm{C}$ selama 14 jam. Koloni bakteri yang tumbuh diduga memiliki plasmid rekombinan. Untuk memastikan hal tersebut, akan dilakukan skrining koloni yang membawa plasmid tersebut dengan teknik PCR koloni.

\section{Transformasi, skrining dan sekuensing}

Skrining terhadap koloni E. coli DH5 $\alpha$ yang membawa plasmid rekombinan dilakukan dengan PCR koloni dengan campuran reaksi sebagai berikut: $0,2 \mathrm{mM}$ dNTP; 0,5 U Ex Taq dan bufernya; 0,5 mM primer pGEX-5' dan pGEX-3', $1 \mu$ sampel (koloni yang telah diencerkan dalam $20 \mu \mathrm{l}$ air steril). Untuk keperluan lebih lanjut, dibuat replika dari koloni bakteri yang diskrining pada media LB yang mengandung ampicilin dan ditumbuhkan pada suhu $37^{\circ} \mathrm{C}$. Program PCR yang digunakan adalah 5 menit pada $94^{\circ} \mathrm{C}, 25$ siklus untuk suhu $94^{\circ} \mathrm{C}$ selama 30 detik, $60^{\circ} \mathrm{C}$ selama 30 detik dan 30 detik pada suhu $72^{\circ} \mathrm{C}$, diakhiri dengan $72^{\circ} \mathrm{C}$ selama 5 menit dan $20^{\circ} \mathrm{C}$ sampai sampel diangkat untuk dielektroforesis. Adanya pita DNA dari gambar hasil elektroforesis merupakan indikasi bahwa klon yang diamplifikasi mengandung plasmid rekombinan. Koloni yang mengandung plasmid rekombinan tersebut pada replika kemudian dikultur pada media LB pada suhu $37^{\circ} \mathrm{C}$ selama 12 jam dengan goyangan untuk isolasi plasmid rekombinan. Isolasi plasmid dilakukan dengan teknik standar (Sambrook et al., 1989). Sekuensing dilakukan setelah amplifikasi dengan Kit Bigdye menurut prosedur Ali (2006) dengan menggunakan primer pGEX-5'. Sekuensing tersebut dimaksudkan untuk memastikan bahwa pada gen target tidak terdapat mutasi.

\section{HASIL DAN PEMBAHASAN}

Selubung virus hepatitis B (hepatitis B virus envelope) terdiri dari membran glikoprotein dimana terdapat 3 bagian protein permukaan yaitu antigen pre-S1 (119 asam amino), pre-S2 (55 asam aminio) dan S (226 asam amino) (Yamada et al., 2001; Jaoude and Sureau, 2005, Barrera et al., 2005). Beberapa ahli menggolongkan ketiga protein tersebut sebagai protein kecil (small), sedang (middle) dan besar (large). Antigen S telah digunakan secara luas sampai saat ini sebagai vaksin konvensional. Menurut $\mathrm{Hu}$ et al (2004), asam amino ke 139-147 pada bagian S merupakan epitop utama pada protein $S$ tersebut. Sedangkan asam amino Pre-S1 dan Pre-S2 masih dikaji tingkat immunogenisitasnya melalui serangkaian diagnosa (Maruyama et al., 2000).

Mengacu kepada Hu et al., (2004) yang menyatakan bahwa asam amino ke 139-147 pada protein bagian S merupakan epitop utama pada protein, maka pada penelitian ini dilakukan amplifikasi hanya dari asam amino ke-100 sampai 164. Adapun jumlah nukleotidanya mencapai 195 pasang basa, namun dengan penambahan adaptor yang sengaja dibuat menyebabkan total produk PCR target mencapai 206 pasang basa. Selain itu, bagian asam amino tersebut dipilih karena merupakan protein yang bersifat hidrophilik, sehingga dapat 
memudahkan ekspresi pada bakteri.

Untuk mendapatkan gen tersebut, berbagai upaya optimalisasi terhadap kondisi reaksi amplifikasi telah dilakukan. Langkahlangkah optimalisasi tersebut diantaranya mengatur suhu dan waktu annealing, mengatur konsentrasi DNA sebagai cetakan dan primer, serta mengatur konsentrasi enzim polymerase DNA.

Campuran PCR yang berhasil digunakan untuk mendapatkan hasil PCR yang optimal adalah 0,1 unit enzim DNA polymerase pyrobest (Takara Bioinc., Otsu, Japan) dengan bufernya; $0,5 \mu \mathrm{M}$ primer forward (f) dan backward (b); 0,2 $\mathrm{mM}$ dNTP; $1 \mathrm{ng} / \mathrm{ml}$ plasmid pGEMT-HB sebagai cetakan. Penggunaan DNA dengan konsentrasi kurang dari $1 \mathrm{ng} / \mathrm{ml}$ menghasilkan pita gen target yang tidak terlalu jelas. Sedangkan penggunaan DNA melebihi 1 ng/ml menyebabkan munculnya beberapa pita produk PCR yang tidak sesuai dengan ukuran pita target. Program PCR yang berhasil digunakan adalah $94^{\circ} \mathrm{C}$ selama 5 menit, 25 siklus pada $94^{\circ} \mathrm{C}$ selama 30 detik, $54^{\circ} \mathrm{C}$ selama 30 detik dan $72^{\circ} \mathrm{C}$ selama 30 detik, diakhiri dengan $72^{\circ} \mathrm{C}$ selama 5 menit dan $20^{\circ} \mathrm{C}$ sampai sampel diangkat untuk dielektroforesis. Untuk menemukan suhu annealing yang ideal $\left(54^{\circ} \mathrm{C}\right)$, telah dilakukan PCR menggunakan beberapa suhuannealing mulai dari $50^{\circ} \mathrm{C}, 52^{\circ} \mathrm{C}$, dan $56^{\circ} \mathrm{C}$. Namun pita gen target terjelas diperoleh pada saat menggunakan suhu $54^{\circ} \mathrm{C}$.

Ketepatan suhu dan waktu annealing, konsentrasi DNA dan primer, serta konsentrasi enzim polymerase DNA yang digunakan sangat menentukan keberhasilan amplifikasi. Penggunaan suhu annealing $54^{\circ} \mathrm{C}$ selama 30 detik telah menyebabkan primer-primer yang digunakan dapat menempel pada daerah spesifik dari DNA cetakan. Selain itu, waktu yang diperlukan untuk tahap extention selama 30 detik pada suhu $72^{\circ} \mathrm{C}$ karena enzim polymerase Pyrobest yang dipergunakan memerlukan waktu 1 menit per 1 kilo pasang basa. Berbeda dengan enzim polymerase Ex Taq yang biasanya memiliki kemampuan lebih cepat, yaitu 40 detik per 1 kilo pasang basa. Hal ini dikarenakan enzim polymerase Pyrobest merupakan enzim dengan tingkat kecermatan tinggi (high fidelity) yang memiliki kemampuan proof-reading.

Produk PCR selanjutnya dimurnikan dari adanya kelebihan primer-primer maupun substrat dan enzim yang digunakan pada campuran PCR dengan teknik pemotongan gel menggunakan DNA Gel extraction kit. Selanjutnya, hasil pemurnian tersebut digunakan pada tahap ligasi dengan plasmid pGEX-4T-2 (Pharmacia) yang telah dipotong dengan enzim Sma1. Karena enzim yang digunakan untuk proses amplifikasi di atas adalah enzimPyrobestyang tergolong enzim yang mempunyai tingkat kecermatan tinggi (high fidelity), maka produk PCR yang dihasilkan berbentuk blunt-end. Oleh karena itu, teknik ligasi yang sesuaiadalah teknik blunt-end.

Campuran reaksi dari reaksi ligasi tersebut adalah produk PCR yang telah diphosphorilasi sebanyak $2 \mu \mathrm{l}, 25 \mathrm{ng} / \mu \mathrm{l}$ plasmid pGEX-4T-2 yang telah diphosphorilasi, $1 \mu \mathrm{l}$ kit ligasi,kemudian diinkubasi pada suhu $12^{\circ} \mathrm{C}$ selama 18 jam. Selanjutnya, dilakukan transformasi dengan E. coli DH5adan kemudian ditumbuhkan pada media LB yang mengandung ampisilin pada suhu $37^{\circ} \mathrm{C}$ selama 14 jam. Koloni bakteri yang tumbuh diduga memiliki plasmid rekombinan. Untuk memastikan hal tersebut, dilakukan skrining koloni yang membawa plasmid tersebut dengan teknik PCR koloni.

Introduksi plasmid pGEX-HB100 ke dalam bakteri inang $E$. coli $D H 5 \alpha$ (transformasi) berhasil dilakukan dengan teknik heat shock.Koloni bakteri E. coli DH5 $\alpha$ pembawa plasmid rekombinan pGEXHB100hasil transformasi ditumbuhkan pada media seleksi (ampisilin $50 \mu \mathrm{l} / \mathrm{ml}$ ) yang mengandung $X$-gal dan IPTG. Hasil kultur dari bakteri tersebut dapat dilihat pada Gambar 2. Koloni bakteri yang berwarna putih diduga membawa plasmid rekombinan pGEX-HB100, sedangkan koloni bakteri yang berwarna biru tidak membawa plasmid 
rekombinan (Gambar 1).

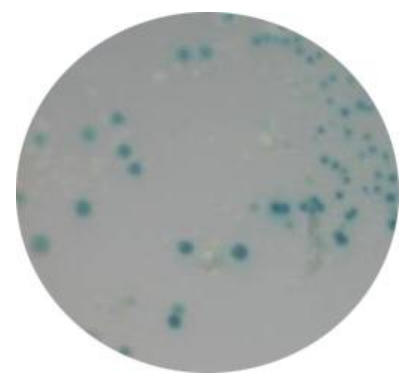

Gambar 1. Koloni E. coli DH5a pembawa plasmid pGEX-HB100hasil transformasi yang ditumbuhkan pada media seleksi (ampisilin). Koloni berwarna putih merupakan koloni bakteri pembawa plasmid rekombinan, sedangkan koloni berwarna biru tidak membawa plasmid rekombinan.

Untuk memastikan bahwa bakteribakteri berwarna putih pembawa gen HB100, maka dilakukan skrining dengan PCR menggunakan koloni bakteri tersebut sebagai cetakan (PCR Koloni). Primer yang digunakan untuk PCR koloni tersebut harus dapat mengamplifikasi bagian 5'-insert dan bagian 3'-dari plasmid. Hal ini dilakukan untuk memastikan tidak terjadi kesalahan arah insert. Amplifikasi hanya akan terjadi pada DNA rekombinan yang tidak tersambung secara terbalik.Adanya pita tunggal DNAdari gambar hasil elektroforesis merupakan indikasi bahwa klon yang diamplifikasi mengandung plasmid rekombinan. Hasil PCR koloni tersebut ditampilkan pada Gambar 2.

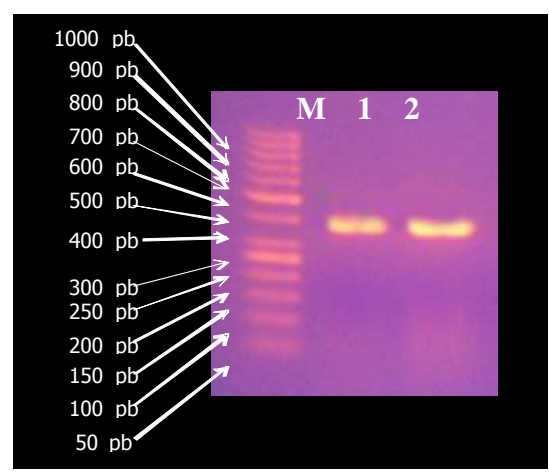

Gambar 2. Hasil elektrophoresis dari PCR koloni. $\mathrm{M}=$ Marker, 1 dan $2=E$. coli $\mathrm{DH} 5 \alpha$ pembawa plasmid pGEX-HB100 sebagai cetakan

Hasil amplifikasi yang kedua ujungnya berbentuk tumpul (blunt end) tersebut memiliki keunggulan sekaligus kelemahan untuk ligasi. Produk PCR yang berujung tumpul akan memudahkan dalam melakukan proses ligasi, dimana hanya dibutuhkan 1 jenis enzim restriksi dengan karakteristik memotong secara langsung untk menghasilkan ujung tumpul juga. Enzim restriksi yang memiliki kemampuan tersebut diantaranya adalah enzim SmaI. Hal ini akan mengurangi biaya penggunaan untuk pembelian enzim restriksi. Namun kelemahannya adalah peluang dihasilkannya gen rekombinan yang benar dan yang salah adalah 50\%. Dengan kata lain, peluang ligasi ujung tumpul pada salah satu ujung produk PCR dengan ujung hasil pemotongan vektor akan sama dengan peluang ligasi dengan arah yang berlawanan.

Kelemahan akibat kedua ujung tumpul produk PCR tersebut dapat diatasi melalui skrining dengan teknik PCR koloni. Primerprimer yang digunakan untuk PCR koloni tersebut harus dapat mengamplifikasi bagian 5'-insert dan bagian 3'-dari plasmid. Amplifikasi hanya akan terjadi pada DNA rekombinan yang tidak tersambung secara terbalik. Jika gen target tersambung secara terbalik, maka PCR koloni tidak akan menghasilkan pita setelah elektrophoresis.

Koloni yang mengandung plasmid rekombinan dengan hasil PCR koloni pita tunggal kemudian dikultur dari replika pada media LB pada suhu $37^{\circ} \mathrm{C}$ selama 12 jam dengan goyangan untuk isolasi plasmid rekombinan. Hasil elektroforesis dari hasil isolasi plasmid rekombinan ditampilkan pada Gambar 3. Pada gambar tersebut terlihat hasil isolasi plasmid rekombinan dengan ukuran sekitar 5.106 pasang basa, yang terdiri dari vektor pGEX-4T-2 mencapai 4.900 pasang basa dan gen target 206 pasang basa.

Plasmid hasil isolasi tersebut kemudian disekuensing. Hasil sekuensing nukleotida disejajarkan dengan sekuen asli virus hepatitis B. Pensejajaran (alignment) 
gen insert dengan bagian genom virus Hepatitis B dapat dilihat pada Gambar4. Hasil pensejajaran (aligment) sekuensing plasmid rekombinan yang diisolasi dari koloni bakteri rekombinan menunjukkan kesamaan dengan sekuen dari bagian genom virus hepatitis B. Hal ini menunjukkan bahwa gen hasil amplifikasi tersebut tidak mengalami mutasi dan dapat digunakan untuk menghasilkan antigen hepatitis B bagian $\mathrm{S}$ pada bakteri. Plasmid rekombinan yang tidak memiliki mutasi pada sekuen insertnya selanjutnya disimpan untuk ditransformasikan pada $E$. coli BL21 untuk memproduksi protein $H B s A g l 00$.

\section{KESIMPULAN DAN SARAN}

Berdasarkan hasil penelitian ini dapat disimpulkan bahwa gen penyandi antigen HBsAgl00 berhasil diamplifikasi, kemudian diligasi dengan vektor pGEX-4T-2, dan ditransformasikan ke dalam bakteri E. coli
DH5 $\alpha$. Hasil sekuensing menunjukkan tidak terdapat mutasi pada gen hasil kloning. Oleh karena itu, penelitian lanjutan yang harus dilakukan adalah uji ekspresi untuk menghasilkan protein rekombinan sebagai kandidat vaksin.

\section{UCAPAN TERIMA KASIH}

Pada kesempatan ini penulis mengucapkan terima kasih kepada Prof. Dr. dr. Mulyanto (Direktur Laboratorium Hepatitis Mataram) yang telah menyediakan bakteri E. coli DH5a pembawa plasmid pGEMT-HB. Juga kepada Dr. Sulaiman Ngongu Depamede dan I Gusti Ayu Sri Andayani, S.Si. (Laboratorium Imunologi Universitas Mataram) serta kepada Dedy Iswaini, S.Pt. dan Susila Yati, S.Si. (Laboratorium Mikrobiologi dan Bioteknologi) atas bantuannya selama penelitian.

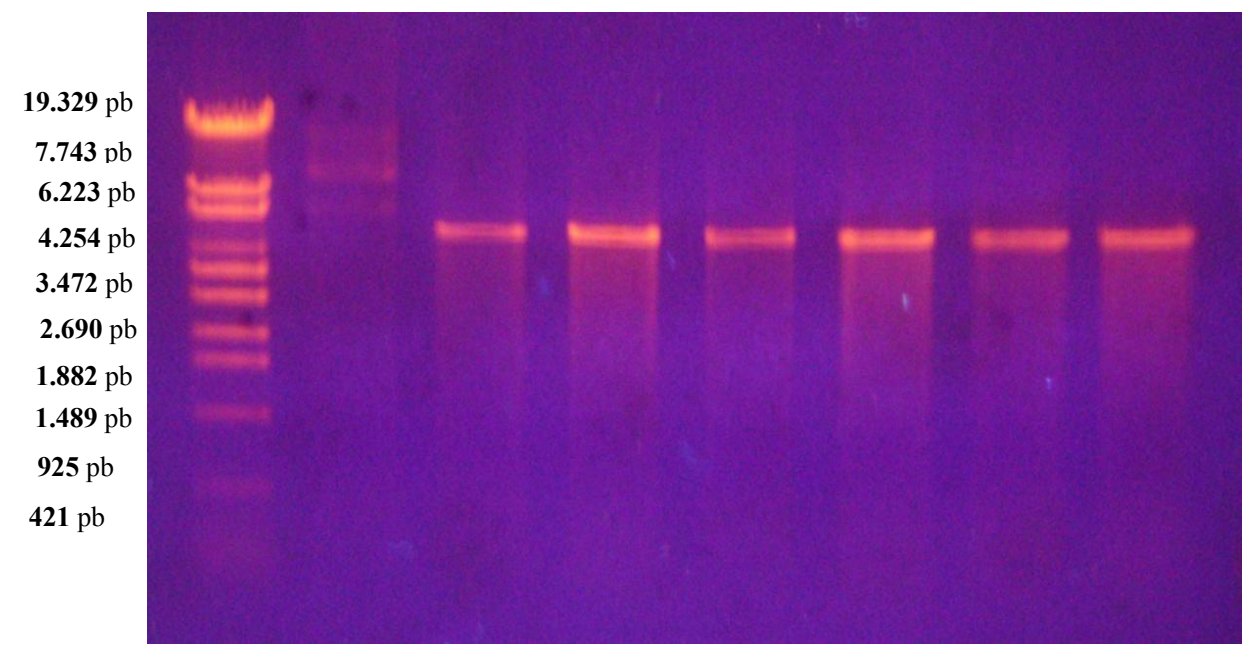

Gambar 3. Pita DNA plasmid pGEX-4T-2 rekombinan hasil elektroforesis dalam 1\% agrosa M : marker DNA $\lambda$. Lajur 1 : Pita DNA plasmid utuh pGEX-4T-2 rekombinan. Lajur 2, 3, 4, 5, 6, 7 : pita DNA plasmid pGEX-4T-2 rekombinan yang dipotong dengan enzim Sma1. 


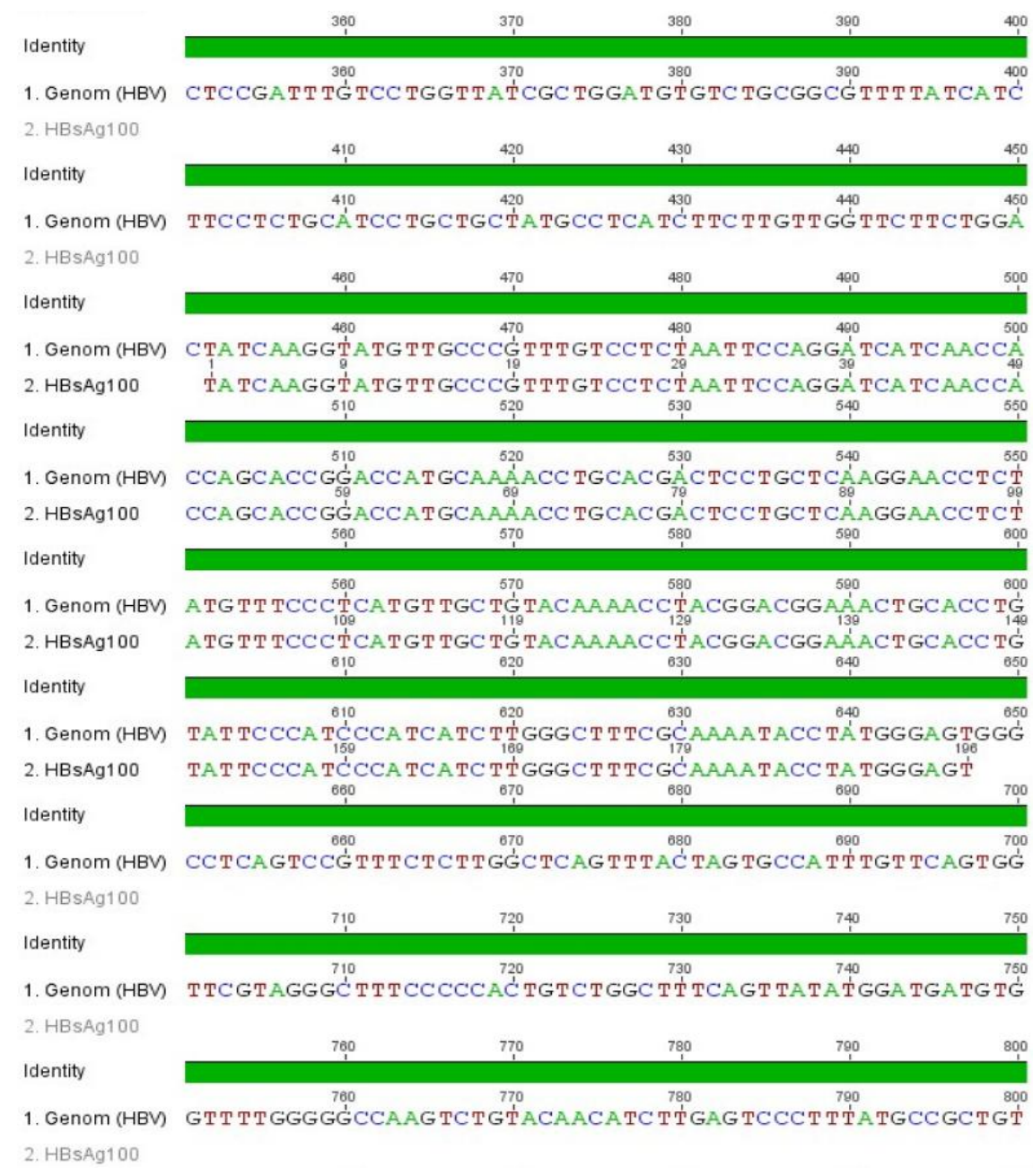

Gambar 4. Alignment sekuen gen insert (penyandi antigen HBsAg100) dengan bagian genom virus Hepatitis B (VHB)

\section{DAFTAR PUSTAKA}

Ali, M. 2006. High-throughput monoclonal antibody production using cell-free protein synthesis system. Ph.D thesis. Nagoya University, Japan. Hu H., Peng XM., Huang YS., Gu L., Xie QF., and Gao ZL. 2004. Yeast expression and DNA immunization of hepatitis B virus gene wiyh secondloop deletion of $\alpha$ determinant region. Word J. Gastroenterol., 10, 2989-2993.

Barrera, A., Guerra, B., Notvall, L., and landford, R. E. 2005. Mapping of the Hepatitis B virus Pre-S1 domain involved in receptor recognition. J. Virology, 79, 9786-9798.

Hu H., Peng XM., Huang YS., Gu L., Xie
QF., and Gao ZL. 2004. Yeast expression and DNA immunization of hepatitis B virus gene wiyh secondloop deletion of $\alpha$ determinant region. Word J. Gastroenterol., 10, 2989-2993.

Jaoude, A. G., and Sureau, C. 2005. Role of the antigenic loop of the hepatitis B virus envelope proteins in infectivity of hepatitis B delta virus. J. Virology, 79, 10460-10466.

Joung, YH., Youm, JW., Jeon, J H., Lee, BC., Ryu, C.J., Hong, HJ., Kim, HC., Joung, H., and Kim, H. S. 2004. Expression of the hepatitis B surface $\mathrm{S}$ and preS2 antigens in tubulers of Solanum tuberosum. Plant Cell Rep, 22; 925-930. (2004). 
Koschorreck M., Fischer M., Barth S., and Pleiss J. 2005. How to find soluble proteins: a comprehensive analysis of alfa/beta hydrolases for recombinant expression in E. coli. BMC Genomics, 6, 1-10.

Kumar, S. G. B., Ganapathi, TR., Revathi, L., Srinivas, VA. and Bapat. 2005. Expression of hepatitis B surface antigen in transgenic pitaana plants. Planta, 222, 484-493.

Lu YY., Li K., Cheng J., Wang L., Liu Y., and Zhang LX. 2002. Cloning and expression of the preS1 gene of hepatitis B virus in yeast cells. Hepatobiliary Pancreat Dis Int. 1, 238242.

Maruyama, J., Ohnuma, H., Yoshikawa, A., Kadokura, H., Nakajima, H., and Kitamoto. 2000. Production and product quality assessment of human hepatitis B virus pre-S2 antigen in submerged and solid-state culture of Aspergillus oryzae. J. Biosci. Bioeng., 90, 118-120.

Muladno. 2002. Tekonologi Rekayasa genetikaa. Bogor Baru: Pustaka Wirausaha Muda. Bogor.

Mulyanto, Soewignjo, S., Gunawan, S., Sumarsidi, D., Kadir, S., and Wiryo, H. 2002. Hepatitis B seroprevalence among children in Mataram, Indonesia: following a seven-year mass immunization program. Report meeting of the US-Japan cooperative medical science program asian region collaboration research project 2001, Sanghai.

Sambrook, J., Fritsch, EF., and Maniatis, T. 1989. Molecular Cloning: A Laboratory Manual. ColdSpringHarbor Laboratory Press, New York.

Sheu SY., and Lo SJ. 1995. Deletion or alteration of hydrophobic amino acids at the firs and third transmembrane domains of hepatitis B surface antigen enhances its production in Escherichia coli. Gene, 160, 179-184.

Vikis HG., and Guan KL. 2000. GlutathioneS-Transferase-Fusion Based Assays for Studying Protein-Protein Interaction. In: Methods in Molecular Biology, vol. 261. Humana Press Inc., Totowa, NJ.

Winarno FG, Agustinah W. 2007. Pengantar Bioteknologi. Ed Revisi. Bogor: MBrio Press.

Yamada T., Iwabuki H., Kanno T., Tanaka H., kawai T., Fukuda H., Kondo A., Seno M., Tanizawa K., and Kuroda S. 2001. Physicochemical and immunological characterization of hepatitis B virus envelope particles exclusively consisting of the entire $\mathrm{L}$ (pre-S1+pre-S2+S) protein. Vaccine, 19, 3154-3163. 